\title{
Desain Teknologi Pembelajaran
}

\section{(Binti Mardiatush S, Charissudin Ruba'I, Fifi Annisa, Luluk Maulida, M. Kholiq S)}

\section{STAI Miftahul ‘Ula Nglawak-Ke rtosono-Nganjuk}

\author{
(bintimardiatus hsholihah@gmail.com)
}

Dosen Pengampu:

Muh. Barid Nizarudin Wajdi, MA.

\begin{abstract}
Abstrak:
Teknologi Pembelajaran adalah studi dan etika praktek untuk memfasilitasi pembelajaran dan meningkatkan kinerja dengan menciptakan, menggunakan, dan mengelola proses teknologi yang sesuai dan sumber daya (AECT 2008). Kawasan teknologi pembelajaran meliputi lima bidang, dimana kawasan desain merupakan salah satu sub dari lima kawasan tersebut. Dalam kawasan desain mencakup penerapan berbagai teori, prinsip, dan prosedur dalam melakukan perencanaan atau mendesain suatu program atau kegiatan pembelajaran yang dilakukan secara sistemis dan sistematis. Kawasan atau ranah desain paling tidak meliputi empat cakupan utama dari teori dan praktek, yaitu desain sistem pembelajaran, desain pesan, strategi pembelajaran, dan karakteristik peserta didik.
\end{abstract}

Kata Kunci: Teknologi Pembelajaran, Desain, Desain Sistem Pembelajaran, Desain Pesan, Strategi Pembelajaran, Karakteristik Peserta Didik. 


\section{A. PENDAhUluan}

Tujuan utama teknologi pembelajaran adalah untuk memecahkan masalah belajar atau memfasilitasi kegiatan pembelajaran. Teknologi pembelajaran sebagai perangkat lunak (software technology) yang berbentuk cara-cara yang sistematis dalam memecahkan masalah pembelajaran semakin canggih dan mendapat tempat secara luas dalam dunia pendidikan (Suparman \& Zuhairi, 2004: 345-346). ${ }^{1}$ Aplikasi praktis teknologi pembelajaran dalam pemecahan masalah belajar mempunyai bentuk kongkrit dengan adanya sumber belajar yang memfasilitasi peserta didik untuk belajar.

Dalam mencapai suatu tujuan, diperlukan perencanaan dalam menentukan langkah apa saja yang dapat ditempuh untuk mencapai tujuan tersebut. Langkah yang diupayakan tersebut hendaklah memiliki indikator yang terukur, untuk memastikan sejauhmana kesenjangan antara perencanaan dengan prektek di lapangan. Ketika upaya dalam mencapai tujuan dapat berjalan dengan optimal, maka secara otomatis mendekatkan kita pada pencapaian tujuan.

Analogi di atas sejalan dengan penerapan teknologi pembelajaran, khususnya dalam kawasan desain. Kawasan desain merupakan salah satu sub dari lima kawasan dalam teknologi pembelajaran. Fokus dalam kawasan desain meliputi segenap langkah perencanaan yang dibutuhkan untuk mewujudkan kegiatan pembelajaran yang efektif. ${ }^{2}$

Kawasan pertama teknologi pembelajaran adalah desain atau perancangan yang mencakup penerapan berbagai teori, prinsip dan prosedur dalam melakukan perencanaan atau mendesain suatu program atau kegiatan pembelajaran yang dilakukan secara sistemis dan sistematis. Yang dimaksud dengan desain disini adalah proses untuk menentukan kondisi belajar dengan tujuan untuk menciptakan strategi dan produk. ${ }^{3}$ Strategi dan produk pada tingkat makro, seperti program dan kurikulum, dan pada tingkat mikro, seperti pelajaran dan modul. ${ }^{4}$

\footnotetext{
${ }^{1}$ M. Atwi Suparman \& A minudin Zuhairi, Pendidikan Jarak Jauh Teori dan Praktek, (Jakarta: Pusat Penerbitan universitas Terbuka, 2004), 345-346.

2 Devit Etika Sari and Muh Barid Nizarudin Wajdi, "The Effectiveness Of The Method of GI With Electronic Workbench Study To Improve Activities and Results Student," Educatio : Journal of Education 2, no. 1 (May 30, 2017): $\quad 136-150, \quad$ accessed October 2017, http://www.ejournal staimnglawak.ac.id/index.php/educatio/article/view/22.

${ }^{3}$ Bambang Warsita, Teknologi Pembelajaran (Jakarta: Rineka Cipta, 2008), 22.

${ }^{4}$ Muh. Barid Nizarudin Wajdi, “المناهج التعليمية للغة العربية في تطوير الدفردات لغير الناطقين بها, " At-Tajdid: Jurnal IImu $\begin{array}{lllllll}\text { Tarbiyah; } & \text { Vol } & 5 & \text { No } & 1 & \text { (2016): } & \text { January } \\ \text { (2016), }\end{array}$
} http://ejournal.stitmuhpacitan.ac.id/index.php/tajdid/article/view/15. 


\section{B. PEMBAHASAN}

Kawasan atau ranah desain paling tidak meliputi empat cakupan utama dari teori dan praktek, yaitu: (1) desain sistem pembelajaran; (2) desain pesan; (3) strategi pembelajaran; dan (4) karakteristik peserta didik. Definisi dan deskripsi dari masingmasing daerah liputan tersebut adalah sebagai berikut:

\section{Desain Sistem Pembelajaran}

Desain sistem pembelajaran adalah prosedur yang terorganisasi dan sistematis untuk:

a. Penganalisaan (proses perumusan apa yang akan dipelajari);

b. Perancangan (proses penjabaran bagaimana cara mempelajarinya);

c. Pengembangan (proses penulisan dan pembuatan atau produksi bahan-bahan pelajaran);

d. Pelaksanaan (pemanfaatan bahan dan strategi) dan

e. Penilaian (proses penentuan ketepatan pembelajaran). ${ }^{5}$

Segala sesuatu perlu untuk direncanakan secara baik, termasuk pembelajaran. Prosedur yang digunakan dalam desain sistem pembelajaran dimaksudkan untuk menghasilkan kegiatan pembelajaran yang efektif dan efisien. ${ }^{6}$

Para pakar teknolog pendidikan telah banyak mengembangkan berbagai model desain sistem pembelajaran, baik model desain makro (meliputi satu rentang waktu kegiatan pensisikan dan pelatihan tertentu) ataupun model desain mikro (meliputi satu pertemuan kegiatan pembelajaran). Dalam penggunaan model tersebut, disesuaikan dengan kebutuhan pembelajaran yang akan diselenggarakan.

Dalam desain pembelajaran dikenal beberapa model yang dikemukakan oleh para ahli. Secara umum, model desain pembelajaran dapat diklasifikasikan ke dalam model berorientasi kelas, model berorientasi sistem, model berorientasi produk, model prosedural dan model melingkar. Model berorientasi kelas biasanya ditujukan untuk mendesain pembelajaran level mikro (kelas) yang hanya dilakukan setiap dua jam pelajaran atau lebih. Contohnya adalah model assure.

Model berorientasi produk adalah model desain pembelajaran untuk menghasilkann suatu produk, biasanya media pembelajaran, misalnya video pembelajaran, multimedia pembelajaran, atau modul. Contoh modelnya adalah model hannafin and peck. ${ }^{7}$

Satu lagi adalah model beroreintasi sistem yaitu model desain pembelajaran untuk menghasilkan suatu sistem pembelajaran yang cakupannya luas, seperti desain sistem suatu pelatihan, kurikulum seiolah, dan lain-lain. contohnya adalah model

\footnotetext{
${ }^{5}$ Barbara B. Seels \& Rita C. Richey, Instructional technology, The definition and domains of the field, Terjemahan Dewi S Prawiradilaga, R. Rahard jo, Yusufhadi Miarso, (Jakarta: Penerbit IPTPI \& LPTK, 2000), 33.

${ }^{6}$ Muh. Barid Nizaruddin Wajdi, "Pendidikan Ideal Menurut Ibnu Khaldun Dalam Muqaddimah," JURNAL LENTERA : Kajian Keaga maan, Keilmuan dan Teknologi 1, no. 2 (September 30, 2015): 272-283, accessed October 24, 2017, http://www. ejournal.staimnglawak.ac.id/index.php/lentera/article/view/49.

${ }^{7}$ Yuli Choirul Ummah and Muh Barid Nizarudin Wajdi, "Dismantling Paradigm Book Ta'limul Muta'allim," Educatio : Journal of Education 1, no. 2 (October 30, 2016): 1-10, accessed October 21, 2017, http://www.ejournal.staimnglawak.ac.id/index.php/educatio/article/view/26.
} 
addie. Selain itu ada pula yang biasa kita sebut sebagai model prosedural dan model melingkar. Contoh dari model prosedural adalah model Dick and Carrey, sementara contoh model melingkar adalah model Kemp.

Adanya variasi model yang ada ini sebenarnya juga dapat menguntungkan, beberapa keuntungan itu antara lain adalah dapat memilih dan menerapkan salah satu model desain pembelajaran yang sesuai dengan karakteristik yang dihadapi di lapangan, selain itu juga, dapat dikembangkan dan dibuat model turunan dari mode lmodel yang telah ada, ataupun juga dapat diteliti dan dikembangkan desain yang telah ada untuk dicobakan dan diperbaiki. Beberapa contoh dari model-model diatas akan diuraikan secara lebih jelas berikut ini:

\section{a. Model Dick and Carrey}

Salah satu model desain pembelajaran adalah model Dick and Carey (1985). Model ini termasuk ke dalam model prosedural. Langkah-langkah Desain Pembelajaran menurut Dick and Carey adalah:

1) Mengidentifikasikan tujuan umum pembelajaran.

2) Melaksanakan analisi pembelajaran

3) Mengidentifikasi tingkah laku masukan dan karakteristik siswa

4) Merumuskan tujuan performansi

5) Mengembangkan butir-butir tes acuan patokan

6) Mengembangkan strategi pembelajaran

7) Mengembangkan dan memilih materi pembelajaran

8) Mendesain dan melaksanakan evaluasi formatif

9) Merevisi bahan pembelajaran

10) Mendesain dan melaksanakan evaluasi sumatif.

Model Dick and Carey bagi perancang pemula sangat cocok sebagai dasar untuk mempelajari model desain yang lain. Kesepuluh langkah pada model Dick and Carey menunjukan hubungan yang sangat jelas, dan tidak terputus antara langkah yang satu dengan yang lainya. Langkah awal pada model Dick and Carey adalah mengidentifikasi tujuan pembelajaran. Langkah ini sangat sesuai dengan kurikulum perguruan tinggi maupun sekolah menengah dan sekolah dasar, khususnya dalam mata pelajaran tertentu di mana tujuan pembelajaran pada kurikulum agar dapat melahirkan suatu rancangan pembangunan.

\section{b. Model Kemp}

Model Kemp termasuk ke dalam contoh model melingkar. Secara singkat, menurut model ini terdapat beberapa langkah dalam penyusunan sebuah bahan ajar, yaitu:

1) Menentukan tujuan dan daftar topik, menetapkan tujuan umum untuk pembelajaran tiap topiknya;

2) Menganalisis karakteristik pelajar, untuk siapa pembelajaran tersebut didesain; 
3) Menetapkan tujuan pembelajaran yang ingin dicapai dengan syarat dampaknya dapat dijadikan tolak ukur perilaku pelajar;

4) Menentukan isi materi pelajaran yang dapat mendukung tiap tujuan;

5) Pengembangan prapenilaian/ penilaian awal untuk menentukan latar belakang pelajar dan pemberian level pengetahuan terhadap suatu topik;

6) Memilih aktivitas pembelajaran dan sumber pembelajaran yang menyenangkan atau menentukan strategi belajar-mengajar, jadi siswa siswa akan mudah menyelesaikan tujuan yang diharapkan;

7) Mengkoordinasi dukungan pelayanan atau sarana penunjang yang meliputi personalia, fasilitas-fasilitas, perlengkapan, dan jadwal untuk melaksanakan rencana pembelajaran;

8) Mengevaluasi pembelajaran siswa dengan syarat mereka menyelesaikan pembelajaran serta melihat kesalahan-kesalahan dan peninjauan kembali beberapa fase dari perencanaan yang membutuhkan perbaikan yang terus menerus, evaluasi yang dilakukan berupa evaluasi formatif dan evaluasi sumatif.

\section{c. Model ASSURE}

Model ASSURE merupakan suatu model yang merupakan sebuah formulasi untuk Kegiatan Belajar Mengajar (KBM) atau disebut juga model berorientasi kelas. Menurut Heinich et al (2005) model ini terdiri atas enam langkah kegiatan yaitu:

1) Analyze Learners (analisis pelajar)

Heinich, 2005 menyatakan sukar untuk menganalisis semua ciri pelajar yang ada, namun ada tiga hal penting dapat dilakuan untuk mengenal pelajar sesuai .berdasarkan cirri-ciri umum, keterampilan awal khusus dan gaya belajar.

2) States Objectives (menyatakan tujuan)

Menyatakan tujuan adalah tahapan ketika menentukan tujuan pembelajaran baik berdasarkan buku atau kurikulum. Tujuan pembelajaran akan menginformasikan apakah yang sudah dipelajari anak dari pengajaran yang dijalankan. Menyatakan tujuan harus difokuskan kepada pengetahuan, kemahiran, dan sikap yang baru untuk dipelajari.

3) Select Methods, Media, and Material (pemilihan metode, media dan bahan) Heinich et.al. (2005) menyatakan ada tiga hal penting dalam pemilihan metode, bahan dan media yaitu menentukan metode yang sesuai dengan tugas pembelajaran, dilanjutkan dengan memilih media yang sesuai untuk melaksanakan media yang dipilih, dan langkah terakhir adalah memilih dan atau mendesain media yang telah ditentukan.

4) Utilize Media and materials (penggunaan media dan bahan)

Menurut Heinich et.al (2005) terdapat lima langkah bagi penggunaan media yang baik yaitu, preview bahan, sediakan bahan, sedikan persekitaran, pelajar dan pengalaman pembelajaran. 
5) Require Learner Participation (partisipasi pelajar di dalam kelas)

Sebelum pelajar dinilai secara formal, pelajar perlu dilibatkan dalam aktivitas pembelajaran seperti memecahkan masalah, simulasi, kuis atau presentasi.

6) Evaluate and Revise

Sebuah media pembelajaran yang telah siap perlu dinilai untuk menguji keberkesanan dan impak pembelajaran. Penilaian yang dimaksud melibatkan beberaoa aspek diantaranya menilai pencapaian pelajar, pembelajaran yang dihasilkan, memilih metode dan media, kualitas media, penggunaan guru dan penggunaan pelajar.

\section{d. Model ADDIE}

Ada satu model desain pembelajaran yang lebih sifatnya lebih generik yaitu model ADDIE (Analysis-Design-Develop-Implement-Evaluate). ADDIE muncul pada tahun 1990-an yang dikembangkan oleh Reiser dan Mollenda.Salah satu fungsinya ADDIE yaitu menjadi pedoman dalam membangun perangkat dan infrastruktur program pelatihan yang efektif, dinamis dan mendukung kinerja pelatihan itu sendiri.

Model ini menggunakan 5 tahap pengembangan yakni :

1) Analysis (analisa)

2) Design (desain / perancangan)

3) Development (pengembangan)

4) Implementation (implementasi/ek sekusi)

5) Evaluation (evaluasi/ umpan balik)

\section{e. Model Hannafin and Peck}

Model Hannafin dan Peck ialah model desain pengajaran yang terdiri daripada tiga fase yaitu fase Analisis keperluan, fase desain, dan fase pengembangan dan implementasi (Hannafin \& Peck 1988). Dalam model ini, penilaian dan pengulangan perlu dijalankan dalam setiap fase. Model ini adalah model desain pembelajaran berorientasi produk.

\section{Desain Pesan}

Desain pesan yaitu perencanaan untuk merekayasa bentuk fisik dari pesan agar terjadi komunikasi antara pengirim dan penerima, dengan memperhatikan prinsip-prinsip perhatian, persepsi, dan daya tangkap. ${ }^{8}$

Pola desain pesan dirancang dengan maksud untuk menarik titik relevansi antara kemampuan peserta didik yang ingin dikembangkan dengan tindakan yang akan diberikan. Tindakan yang diberikan tersebut berupa menentukan sumber belajar dan pola penyajiannya, dengan menggunakan alat, bahan, teknik, orang, pesan, dan lingkungan. Terdapat beberapa prinsip dalam desain pesan yang perlu diperhatikan agar dapat berjalan dengan efektif, yakni : ${ }^{9}$

\footnotetext{
${ }^{8}$ Ibid.,33-34.

${ }^{9}$ Bambang Warsita, Teknologi Pembelajaran........,24.
} 
a. Kesiapan dan motivasi (readiness and motivation)

b. Penggunaan alat pemusat perhatian (attention directing devices)

c. Partisipasi aktif peserta didik (student's active participation)

d. Perulangan (repetition)

e. Umpan balik (feedback)

Desain pesan berkaitan dengan hal-hal mikro, seperti : bahan visual, urutan, halaman dan layar secara terpisah. Desain harus bersifat spesifik, baik tentang media maupun tugas belajarnya. Hal ini mengandung makna bahwa prinsip-prinsip desain pesan akan berbeda, bergantung pada jenis medianya, apakah bersifat statis, dinamis atau kombinasi keduanya (misalnya, suatu potret, film, atau grafik komputer). Juga apakah tugas belajarnya tentang pembentukan konsep, pengembangan sikap, pengembangan keterampilan, strategi belajar atau hafalan.

Ada tiga langkah pokok dalam mendesain pesan bila menggunakan pendekatan sistem, yaitu : menentukan masalah, mengembangkan alternatif pemecahan masalah dan menilai pelaksanaan alternatif yang dipilih untuk di revisi. Penyususnan rancangan pesan dihubungkan dengan pertemuan tatap muka untuk pencapaian tujuan belajar tertentu saja.

Langkah-langkah desain pesan pembelajaran menurut Jerrord E. Kemp terdiri dari delapan langkah, yaitu :

a. Pertimbangkan dahulu tujuan program pendidikan diarahkan untuk mecapai tujuan tersebut. Berdasarkan kurikulum, pilihlah topik-topik yang akan diberikan, untuk masing-masing topik perlu dirumuskan tujuan umum pengajarannya secara eksplisit.

b. Pelajari karakteristik siswa.

c. Rumusan tujuan belajar yang harus dicapai dengan menggunakan kriteria tingkah laku yang dapat diamati dan diukur.

d. Membuat daftar perincian isi pembelajaran yang dapat mendukung tercapainya tujuan.

e. Mengembangkan alat ukur pendahuluan untuk menentukan latar belakang siswa dan tingkatan pengetahuan siswa untuk topik yang akan diajarkan.

f. Menentukan dan memilih kegiatan belajar mengajar dan sumber-sumber pembelajaran yang akan digunakan untuk mengolah isi pengajaran sehingga siswa dapat mencapai tujuan yang telah dirumuskan.

g. Koordinasikan hal-hal yang dapat memberikan dukungan dalam melaksanakan kegiatan belajar mengajar yang sesungguhnya, seperti dana, ketenagaan, fasilitas, peralatan, dan jadwal untuk melaksanakaan kegitan pembelajaran.

h. Menilai belajar siswa dikaitka dengan seberapa jauh mereka telah mencapai tujuan pembelajaran dengan disertai pandagan bahwa rencana yang sudah 
direncanakan perlu diperbaiki bila diperlukan berdasarkan masukan atau feedback yang diperoleh dari pelksanaan penilaian yang telah dilakukan.

\section{Strategi Pembelajaran}

Strategi pembelajaran yaitu spesifikasi untuk menyeleksi serta mengurutkan peristiwa belajar atau kegiatan pembelajaran dalam suatu mata pelajaran. ${ }^{10}$ Strategi pembelajaran menjawab pertanyaan mengenai hal apa saja yang harus dilakukan oleh pendidik di dalam kelas dalam proses pembelajaran pserta didik, agar materi pelajaran yang diharapkan dapat dikuasai oleh peserta didik dan dapat diterima dengan baik. Prosedur yang perlu dilakukan dalam strategi pembelajaran, meliputi:

a. Komponen pertama yaitu urutan kegiatan pembelajaran.

Mengurutkan kegiatan pembelajaran dapat memudahkan guru dalam pelaksanaan kegiatan mengajarnya, guru dapat mengetahui bagaimana ia harus memulainya, menyajikannya dan menutup pelajaran.

1) Sub komponen pendahuluan, merupakan kegiatan awal dalam pembelajaran. Kegiatan ini mempunyai tujuan untuk memberikan motivasi kepada siswa, memusatkan perhatian siswa agar siswa bisa mempersiapkan dirinya untuk menerima pelajaran dan juga mengetahui kemampuan siswa atau apa yang telah dikuasai siwa sebelumnya dan berkaitan dengan materi pelajaran yang akan disampaikan. Hal-hal yang dilakukan pada tahap ini adalah memberikan gambaran singkat tentang isi pelajaran, penjelasan relevansi isis pelajaran baru, dan penjelasan tentang tujuan pembelajaran.

2) Sub komponen penyajian, kegiatan ini merupakan inti dari kegiatan belajar mengajar. Dalam kegiatan ini pembelajar akan ditanamkan pengetahuan baru dan pengetahuan yang telah dimiliki dikembangkan pada tahap ini. Tahaptahapnya adalah menguraikan materi pelajaran, memberikan contoh dan memberikan latihan yang disesuaikan dengan materi pelajaran.

3) Sub komponen penutup, merupakan kegiatan akhir dalam urutan kegiatan pembelajaran. Dilaksanakan untuk memberikan penegasan atau kesimpulan dan penilaian terhadap penguasaan materi pelajaran yang telah diberikan.

b. Komponen kedua yaitu metode pembelajaran.

Metode pembelajaran adalah cara yang digunakan oleh pengajar dalam menyampaikan pesan pembelajaran kepada pembelajar dalam mencapai tujuan pembelajaran. Pengajar atau guru harus dapat memilih metode yang tepat yang disesuaikan dengan materi pelajaran agar tujuan pembelajaran dapat tercapai. Metode pembelajaran mungkin dapat dikatakan tepat untuk suatu pelajaran tetapi belum tentu tepat untuk pelajaran yang lainnya, untuk itu guru haruslah pandai dalam memilih dan menggunakan metode-metode pembelajaran mana yang akan

${ }^{10}$ Barbara B. Seels \& Rita C. Richey, Instructional technology. 
digunakan dan disesuaikan dengan materi yang akan diberikan dan karakteristik siswa.

c. Komponen ketiga yaitu media yang digunakan.

Media adalah segala bentuk dan saluran yang digunakan untuk menyampaikan pesan atau informasi. Media dapat berbentuk orang/guru, alat-alat elektronik, media cetak,dsb. Hal-hal yang harus dipertimbangkan dalam memilih media adalah :

1) Ketepatan dengan tujuan pembelajaran

2) Dukungan terhadap isi pelajaran

3) Kemudahan memperoleh media

4) Keterampilan guru dalam menggunakannya

5) Ketersediaan waktu menggunakannya

6) Sesuai dengan taraf berpikir siswa.

d. Komponen keempat adalah waktu tatap muka.

Pengajar harus tahu alokasi waktu yang diperlukan dalam menyelesaikan pembelajaran dan waktu yang digunakan pengajar dalam menyampaikan informasi pembelajaran. Sehingga proses pembelajaran berjalan sesuai dengan target yang ingin dicapai.

e. Komponen kelima adalah pengelolaan kelas.

Kelas adalah ruangan belajar (lingkungan fisik) dan lingkungan sosio-emosional. Lingkungan fisik meliputi: ruangan kelas, keindahan kelas, pengaturan tempat duduk, pengaturan sarana atau alat-alat lain, dan ventilasi dan pengaturan cahaya. Sedangkan lingkungan sosio-emosional meliputi tipe kepemimpinan guru, sikap guru, suara guru, pembinaan hubungan baik, dsb. Pengelolaan kelas menyiapkan kondisi yang optimal agar proses belajar mengajar dapat berlangsung secara lancar

\section{Karakteristik Peserta Didik}

Karakteristik peserta didik yaitu aspek latar belakang pengalaman peserta didik yang mempengaruhi terhadap efektivitas proses belajarnya. ${ }^{11}$ Dalam memberikan tindakan kepada peserta didik, menjadi keharusan bagi pendidik untuk memahami bagaimana karakteristik peserta didik dan keterhubungannya dengan materi pelajaran, yang meliputi:

a. Analisa kemampuan awal peserta didik, yang mencakup pengetahuan, keterampilan, dan sikapnya terhadap suatu materi pelajaran.

b. Analisa tipe kecerdasan peserta didik. Menurut Howard Gardner (1983), manusia masing-masing memiliki 8 tipe kecerdasan namun dengan tingkatan yang berbeda-beda, meliputi verbal-linguistik, matematis-logis, ruang-visual, intrapersonal, interpersonal, musikal, kinestetik-badani, dan lingkungan. Selain itu, terdapat pula kecerdasan spiritual dan eksistensial. Tugas pendidik adalah

${ }^{11}$ Ibid., 35 . 
mendeteksi kelebihan tipe kecerdasan masing-masing peserta didik agar dapat memberikan tindakan belajar yang relevan.

c. Analisa karakteristik peserta didik. Sebagai referensi, pendidik perlu memahami disiplin ilmu psikologi pendidikan dan perkembangan peserta didik, khususnya sub kajian karakteristik peserta didik, yang meliputi karakteristik fisik, moral, intelektual, sosial, emosional, dan spiritual sesuai dengan jenjang fase usia.

Dengan memahami keunikan dari masing-masing karakteristik peserta didik, diharapkan pendidik dapat memberikan tindakan belajar yang tepat dan dapat merancang kegiatan pembelajaran yang mengakomodir seluruh gaya belajar dari tiap individu. 


\section{PENUTUP}

Teknologi Pembelajaran adalah studi dan etika praktek untuk memfasilitasi pembelajaran dan meningkatkan kinerja dengan menciptakan, menggunakan, dan mengelola proses teknologi yang sesuai dan sumber daya (AECT 2008). Tujuan utama teknologi pembelajaran adalah untuk memecahkan masalah belajar atau memfasilitasi kegiatan pembelajaran. Teknologi pembelajaran sebagai perangkat lunak (sofware technology) yang berbentuk cara-cara yang sistematis dalam memecahkan masalah pembelajaran semakin canggih dan mendapat tempat secara luas dalam dunia pendidikan. Aplikasi praktis teknologi pembelajaran dalam pemecahan masalah belajar mempunyai bentuk kongkrit dengan adanya sumber belajar yang memfasilitasi peserta didik untuk belajar.

Kawasan pertama teknologi pembelajaran adalah desain atau perancangan yang mencakup penerapan berbagai teori, prinsip dan prosedur dalam melakukan perencanaan atau mendesain suatu program atau kegiatan pembelajaran yang dilakuk an secara sistemis dan sistematis. Yang dimaksud dengan desain disini adalah proses untuk menentukan kondisi belajar dengan tujuan untuk menciptakan strategi dan produk. Strategi dan produk pada tingkat makro, seperti program dan kurikulum, dan pada tingkat mikro, seperti pelajaran dan modul.

Kawasan atau ranah desain paling tidak meliputi empat cakupan utama dari teori dan praktek, yaitu: (1) desain sistem pembelajaran; (2) desain pesan; (3) strategi pembelajaran; dan (4) karakteristik peserta didik. 


\section{REFERENCES}

Seels, Barbara B. \& Richey, Rita C., (2000), Instructional technology, The definition and domains of the field, Terjemahan Dewi S Prawiradilaga, R. Rahardjo, Yusufhadi Miarso, Jakarta: Penerbit IPTPI \& LPTK.

Suparman, M. Atwi \& Zuhairi, Aminudin (2004), Pendidikan Jarak Jauh Teori dan Praktek, Jakarta: Pusat Penerbitan universitas Terbuka.

Warsita, Bambang. 2008. Teknologi Pembelajaran. Jakarta: Rineka Cipta

Sari, Devit Etika, and Muh Barid Nizarudin Wajdi. "The Effectiveness Of The Method of GI With Electronic Workbench Study To Improve Activities and Results Student." Educatio : Journal of Education 2, no. 1 (May 30, 2017): 136-150. Accessed October 24, 2017. http://www.ejournal. staimnglawak.ac.id/index.php/educatio/article/view/22.

Ummah, Yuli Choirul, and Muh Barid Nizarudin Wajdi. "Dismantling Paradigm Book

Ta' limul Muta'allim." Educatio : Journal of Education 1, no. 2 (October 30, 2016): 1-10. Accessed October 21, 2017.

http://www.ejournal.staimnglawak.ac.id/index.php/educatio/article/view/26.

Wajdi, Muh. Barid Nizaruddin. "Pendidikan Ideal Menurut Ibnu Khaldun Dalam

Muqaddimah." JURNAL LENTERA : Kajian Keagamaan, Keilmuan dan Teknologi 1, no. 2 (September 30, 2015): 272-283. Accessed October 24, 2017.

http://www.ejournal.staimnglawak.ac.id/index.php/lentera/article/view/49.

Wajdi, Muh. Barid Nizarudin. “ المناهج التعليمية للغة العربية في تطوير المفردات لغير الناطقين بها

Tajdid: Jurnal Ilmu Tarbiyah; Vol 5 No 1 (2016): January 2016 (2016). http://ejournal.stitmuhpacitan.ac.id/index.php/tajdid/article/view/15. 